\title{
Analisis Pola Sirkulasi Arus di Perairan Pantai Sungai Duri Kabupaten Bengkayang Kalimantan Barat
} Suandia, Muh. Ishak Jumaranga*, Apriansyah ${ }^{\mathrm{b}}$

aJurusan Fisika, Fakultas MIPA Universitas Tanjungpura bJurusan Ilmu Kelautan, Fakultas MIPA Universitas Tanjungpura

Jalan Prof. Dr. H. Hadari Nawawi, Pontianak, Indonesia *Email : ishakjumarang@physics.untan.ac.id

\begin{abstract}
Abstrak
Telah dilakukan penelitian untuk menganalisis pola sirkulasi arus di Perairan Pantai Sungai Duri Kabupaten Bengkayang Kalimantan Barat. Data pasang surut dan angin tahun 2014 digunakan sebagai input untuk menentukan pola sirkulasi arus.Metode numerikyang digunakan untuk menentukan pola sirkulasi arus adalah metode volume hingga. Sementara data angin dan pasut digunakan sebagai nilai input model. Analisis pola sirkulasi arus dilakukan pada empat kondisi musim yang ada di Indonesia, yaitu musim Barat, peralihan I, musim Timur dan peralihan II. Hasil simulasi model menunjukkan elevasi muka air laut pada musim Barat berkisar antara -0,30 s.d. 0,44 m. Kecepatan arus pada musim Barat berkisar antara 0,02 s.d. 0,65 m/s, dengan arah arus cenderung ke Utara hingga Barat Daya. Elevasi muka air laut pada kondisi peralihan I berkisar antara -0,19 s.d. 0,29 m. Kecepatan arus pada kondisi peralihan I berkisar antara 0,02 s.d. 0,30 m/s, dengan arah arus cenderung ke Timur Laut hingga Tenggara. Elevasi muka air laut pada musim Timur berkisar antara -0,23 s.d. 0,34 m. Kecepatan arus pada musim Timur berkisar antara 0,02 s.d. 0,44 m/s, dengan arah arus cenderung sama dengan musim Barat yakni ke Utara hingga Barat Daya. Elevasi muka air laut pada kondisi peralihan II berkisar antara -0,10 s.d. 0,09 m. Kecepatan arus pada kondisi peralihan II berkisar antara 0,02 s.d. 0,72 m/s, dengan arah arus cenderung ke Barat hingga Tenggara. Hasil kecepatan arus tertinggi berada pada kondisi peralihan II yaitu 0,72 m/s.
\end{abstract}

Kata Kunci : Elevasi Muka Air Laut,Sirkulasi Arus, Volume Hingga

\section{Latar Belakang}

Kalimantan Barat merupakan salah satu propinsi yang terletak di Pulau Kalimantan. Propinsi ini memiliki keistimewaan yakni dilalui garis khatulistiwa (equator) dan terdapat sungai terpanjang di Indonesia yaitu Sungai Kapuas dengan panjang $1.178 \mathrm{~km}$ [1]. Selain memiliki sungai terpanjang di Indonesia, Kalimantan Barat juga memiliki beberapa sungai yang bermuara di Selat Karimata, salah satunya adalah Sungai Duri, yang terletak di Desa Sungai DuriKabupaten Bengkayang.

Daerah pantai yang sering disebut sebagai wilayah pesisir merupakan wilayah yang saling mempengaruhi antara lingkungan daratan dan lautan yang mendapat pengaruh laut seperti pasang surut, angin laut dan perembesan air laut yang merupakan salah satu faktor yang dapat menyebabkan abrasi di pesisir pantai.Segala aktivitas yang terjadi di Pesisir Pantai Sungai Duri membutuhkan adanya pemahaman hidrodinamika guna mengetahui perubahan kondisi pola sirkulasi arus. Cara yang digunakan untuk mengetahuinya sangat beragam seperti pemodelan fisik yang membutuhkan banyak biaya, waktu, dan ruang yang cukup luas dalam memodelkannya serta tidak fleksibel dalam membuat berbagai skenario yang dibutuhkan. Salah satu kajian yang banyak digunakan adalah dengan menggunakan metode numerik dimana lebih efisien saat melakukan tahapan-tahapan pemodelan dan dapat melakukan berbagai macam skenario untuk perbandingan hasil dan kajian yang dibutuhkan.

Metode yang digunakan dalam penelitian ini adalah dengan metode numerik volume hingga. Metode ini merupakan metode dengan pemodelan numerik yang sudah teruji dan sudah digunakan oleh penelitian sebelumnyadengan kajian simulasi pola sirkulasi arus di Muara Sungai Kapuas Kalimantan Barat [2]. Sistem pemodelan yang digunakan dalam metode numerik ini dapat digunakan untuk mengetahui kondisi hidrodinamika sepertitransport sedimen, pasang surut dan pola sirkulasi arus pada daerah pesisir pantai, muara sungai dan lainlain.

\section{Metodologi}

\subsection{Lokasi dan Waktu Penelitian}

Penelitian ini dilakukan di Perairan Pantai Sungai Duri Kabupaten Bengkayang Kalimantan Barat.Daerah model meliputi $0,5130^{\circ}$ s.d. $0,6250^{\circ} \mathrm{LU}$ dan $108,8720^{\circ}$ s.d. $108,9280^{\circ} \mathrm{BT}$, seperti yang terlihat pada Gambar 1 . 


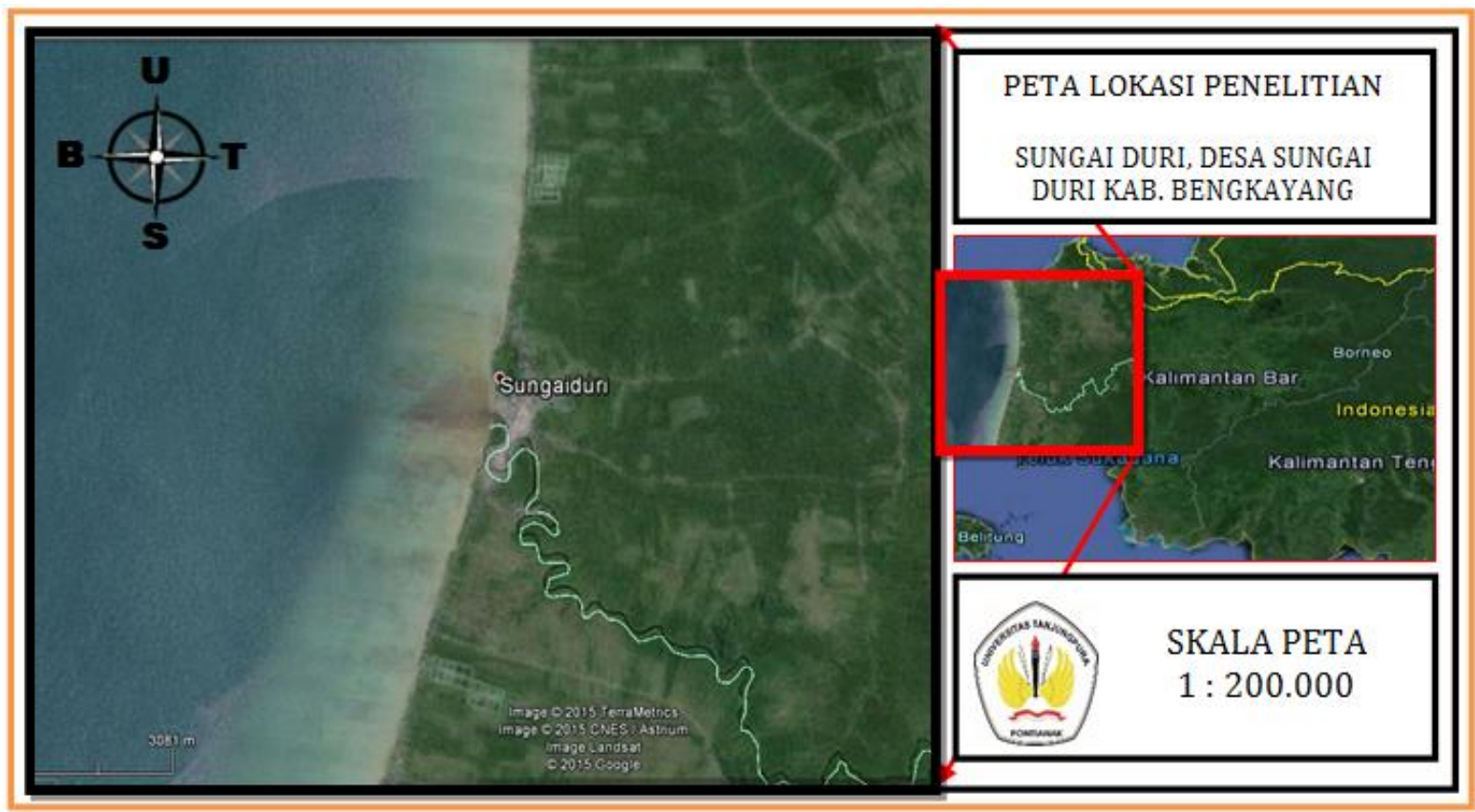

Gambar 1.Peta lokasi penelitian [3]

\subsection{Data Penelitian}

\subsubsection{Data Batimetri}

Data kedalaman perairan atau data batimetri daerah penelitian didapat dari hasil digitasi Peta Perairan Kalimantan Barat yang diperoleh dari Dinas Hidro-Oseanografi tahun 2014. Data tersebut berupa data garis pantai dan data kedalaman daerah perairan lokasi penelitian.

\subsubsection{Data Debit Sungai}

Data debit sungai didapatkan dari hasil perhitungan menggunakan data kedalaman, lebar dan kecepatan aliransungai. Data kedalaman dan lebar sungai digunakan untuk mendapatkan luas penampang Sungai Duri. Adapun persamaan untuk menghitung debit sungai sebagai berikut :

$$
Q=A \cdot V
$$

dengan $Q$ adalah data debit sungai $\left(\mathrm{m}^{3} / \mathrm{s}\right), A$ adalahluas penampang sungai $\left(\mathrm{m}^{2}\right)$ dan $V$ adalah kecepatan aliransungai $(\mathrm{m} / \mathrm{s})$.

\subsubsection{Data Resultan Kecepatan dan Arah Angin}

Data angin diperoleh dari ECMWF [4]. Data angin yang digunakan adalah kecepatan angin periode 6 jam tahun 2014 untuk komponen $u$ dan $v$ pada ketinggian 10 meter di atas permukaan laut. Nilai komponen $u$ pada kecepatan angin adalah nilai kecepatan angin dalam arah vektor $\mathrm{x}$ dalam satuan $\mathrm{m} / \mathrm{s}$ atau arah Timur-Barat atau yang biasa disebut dengan angin zonal, sementara nilai $v$ adalah nilai kecepatan angin dalam arah vektor $\mathrm{y}$ dalam satuan $\mathrm{m} / \mathrm{s}$ atau dalam arah Utara-Selatan atau yang biasa disebut dengan angin meridiornal. Kemudian data angin tersebut dicari nilai resultan kecepatan dan arah angin sebagai data input model. Nilai resultan kecepatan angin dapat ditentukan dengan menggunakan persamaan sebagai berikut :

$$
U=\sqrt{u^{2}+v^{2}}
$$

dengan $U$ adalah resultan kecepatan angin $(\mathrm{m} / \mathrm{s})$. Sedangkan arah angin ditentukan dengan menggunakan persamaan sebagai berikut :

$$
\theta=\arctan \frac{v}{u}
$$

dengan $\theta$ merupakan arah angin yang berhembus.

\subsubsection{Data Pasang Surut}

Data pasang surut diperlukan sebagai pembangkit arus untuk daerah terbuka yaitu batas wilayah Barat, Selatan dan Utara. Data pasang surut ini diperoleh dari hasil prediksi TMD (Tidal Model Driver) berupa data ketinggian muka air perjam untuk daerah simulasi.

\subsection{Cara Kerja Penelitian \\ 2.3.1 Pemodelan}

Metode pemodelan yang digunakan pada penelitian ini yaitu metode numerik volume hingga. Data yang telah dikonversikan di-input sebagai coasline (garis pantai) dan diolah dengan metode numerik volume hingga untuk mendapatkan ruang model. Nilai awal dianggap konstant, dimana kedalaman aliran dan kecepatan aliran dianggap nol. Syarat batas yang 
diterapkan pada kasus ini dibagi menjadi dua bagian yaitu syarat batas aliran dan syarat batas dinding atau daratan. Untuk syarat batas aliran, jika data debit dan tinggi muka air di sebelah hulu atau hilir diberikan, maka digunakan untuk menentukan besarnya kecepatan aliran. Namun, dapat pula syarat batas aliran ditentukan dengan menetapkan besarnya tinggi muka air dan kecepatan aliran. Syarat batas dinding atau daratan yang diterapkan dianggap tidak ada aliran yang keluar atau masuk dinding.

\subsubsection{Persamaan Pengatur}

Pergerakan massa air (hidrodinamika) di suatu perairan dapat dipelajari dengan menggunakan hukum kekekalan massa (kontinuitas) dan kekekalan momentum. Adapun persamaan kontinuitas sebagai berikut :

$$
\frac{\partial h}{\partial t}+\frac{\partial h \bar{u}}{\partial x}+\frac{\partial h \bar{v}}{\partial y}=h S
$$

Persamaan momentum dalam arah $\mathrm{x}$ dan $\mathrm{y}$ :

$$
\begin{aligned}
& \frac{\partial h \bar{u}}{\partial t}+\frac{\partial h \bar{u}^{2}}{\partial x}+\frac{\partial h \overline{v u}}{\partial y}=f \bar{v} h-g h \frac{\partial \eta}{\partial x} \\
& -\frac{g h^{2}}{2 \rho_{0}} \frac{\partial \rho}{\partial x}+\frac{\tau_{s x}}{\rho_{0}}-\frac{\tau_{b x}}{\rho_{0}}+\frac{\partial}{\partial x}\left(h T_{x x}\right) \\
& +\frac{\partial}{\partial y}\left(h T_{x y}\right)+h u_{s} S
\end{aligned}
$$

$$
\begin{aligned}
& \frac{\partial h \bar{v}}{\partial t}+\frac{\partial h \overline{u v}}{\partial x}+\frac{\partial h \bar{v}^{2}}{\partial y}=f \bar{u} h-g h \frac{\partial \eta}{\partial y} \\
& -\frac{g h^{2}}{2 \rho_{0}} \frac{\partial \rho}{\partial y}+\frac{\tau_{s y}}{\rho_{0}}-\frac{\tau_{b y}}{\rho_{0}}+\frac{\partial}{\partial x}\left(h T_{x y}\right) \\
& +\frac{\partial}{\partial y}\left(h T_{y y}\right)+h v_{s} S
\end{aligned}
$$

dengan $t$ adalah waktu, $x$ dan $y$ merupakan koordinat kartesian, $\eta$ adalah elevasi muka air laut, $d$ adalah kedalaman perairan, $h=\eta+d$ adalah kedalaman total, $u$ dan $v$ masingmasing komponen kecepatan dalam arah $x$ dan $y, f=2 \Omega \sin \varphi$ adalah parameter Coriolis, $g$ adalah percepatan gravitasi bumi, $\rho$ adalah densitas air, $v_{t}$ adalah viskositas eddy, $P_{a}$ adalah tekanan atmosfer dan $S$ adalah magnitudo debit sungai [5].

\subsubsection{Desain Simulasi}

Simulasi dilakukan untuk empat kondisimusimyang berbeda pada tahun 2014, yaitu musim Barat (Desember, Januari dan Februari), kondisi peralihan I (Maret, April dan Mei), musim Timur (Juni, Juli dan Agustus) dan kondisi peralihan II (September, Oktober dan November). Domain model terdiri dari tiga batas terbuka, yaitu batas terbuka Utara, Barat dan Selatan. Pada tiap titik di batas terbuka ini menggunakan elevasi pasang surut prediksi Tidal Model Driver (TMD).

Simulasi dilakukan dengan skenario angin dan pasang surut sebagai pembangkit arus. Pada skenario, dilakukan verifikasi hasil model dengan menggunakan data lapangan dan hasil prediksi Tidal Model Driver (TMD) [6].

\subsection{Analisis Hasil Model}

Sebelum dianalisis, terlebih dahulu dilakukan verifikasi untuk memastikan apakah hasil simulasi sesuai atau tidak dengan data lapangan atau hasil penelitian lain. Setelah diverifikasi, hasil model kemudian dianalisis guna mengetahui keadaan pola sirkulasi arus yang dilakukan pada empat bulan perwakilan kondisi musim yang ada di Indonesia, yaitu Januari (musim Barat), April (kondisi Peralihan I), Juli (musim Timur) dan Oktober (kondisi Peralihan II).

Hasil simulasi yang baik dari metode yang digunakan dinyatakan dalam tingkat kesalahan atau error dari sebuah metode. Tingkat kesalahan atau error didapatkan dengan menghitung Root Mean Square Error (RMSE) dengan menggunakan persamaan sebagai berikut [7]:

$$
R M S E=\sqrt{\frac{1}{N} \sum_{i=1}^{N}\left(e_{i}-\hat{e}_{i}\right)^{2}}
$$

dengan $e_{i}$ adalah data lapangan dan $\hat{e}_{i}$ adalah data simulasi atau prediksi. 


\subsection{Diagram Alir Penelitian}

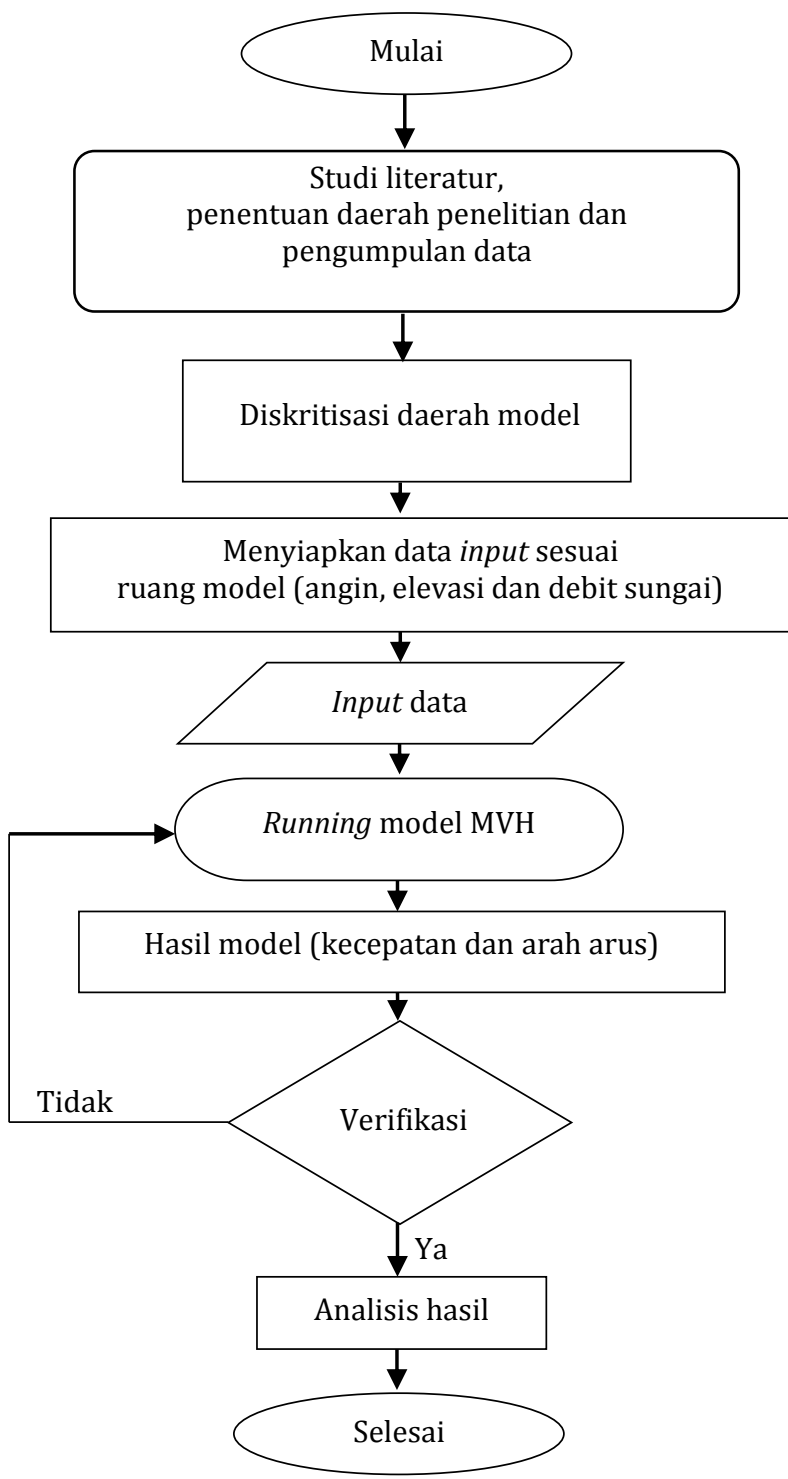

\section{Hasil dan Pembahasan}

\subsection{Verifikasi Nilai Kecepatan Arus dan} Pasang Surut (Pasut)

Verifikasi kecepatan arus dan pasut hasil simulasi model dilakukan terhadap data hasil pengukuran lapangan di daerah Sungai Duri [8]. Data lapangan meliputi data kecepatan arus dan pasang surut selama tiga hari dari tanggal 16 s.d. 19 Desember 2008. Nilai RMSE kecepatan arus data lapangan dan data model sebesar 0,08 sedangkan nilai RMSE untuk data pasang surut lapangan dan prediksi TMD sebesar 0,13.

Gambar 3 merupakan grafik verifikasi kecepatan arus data hasil simulasi dengan data lapangan di titik yang sama. Grafik menunjukkan kecepatan arus yang relatif sama antara hasil simulasi dengan data lapangan. Verifikasi ini dilakukan menggunakan data lapangan bulan Desember tahun 2008 terhadap data hasil simulasi pada tanggal, bulan dan tahun yang sama sebagai data pembandingnya.

Hasil simulasi yang dilakukan pada daerah model meliputi elevasi muka air dan arus (kecepatan dan arah). Hasil tersebut mewakili empat bulan berbeda pada tahun 2014 yaitu; Januari (bulan basah atau musim hujan), April (musim peralihan I), Juli (bulan kering atau musim kemarau), dan Oktober (musim peralihan II). Masing-masing bulan tersebut dicuplik ketika pasang tertinggi, pasang menuju surut terendah, surut terendah dan surut menuju pasang tertinggi.

Gambar 2. Diagram Alir Penelitian

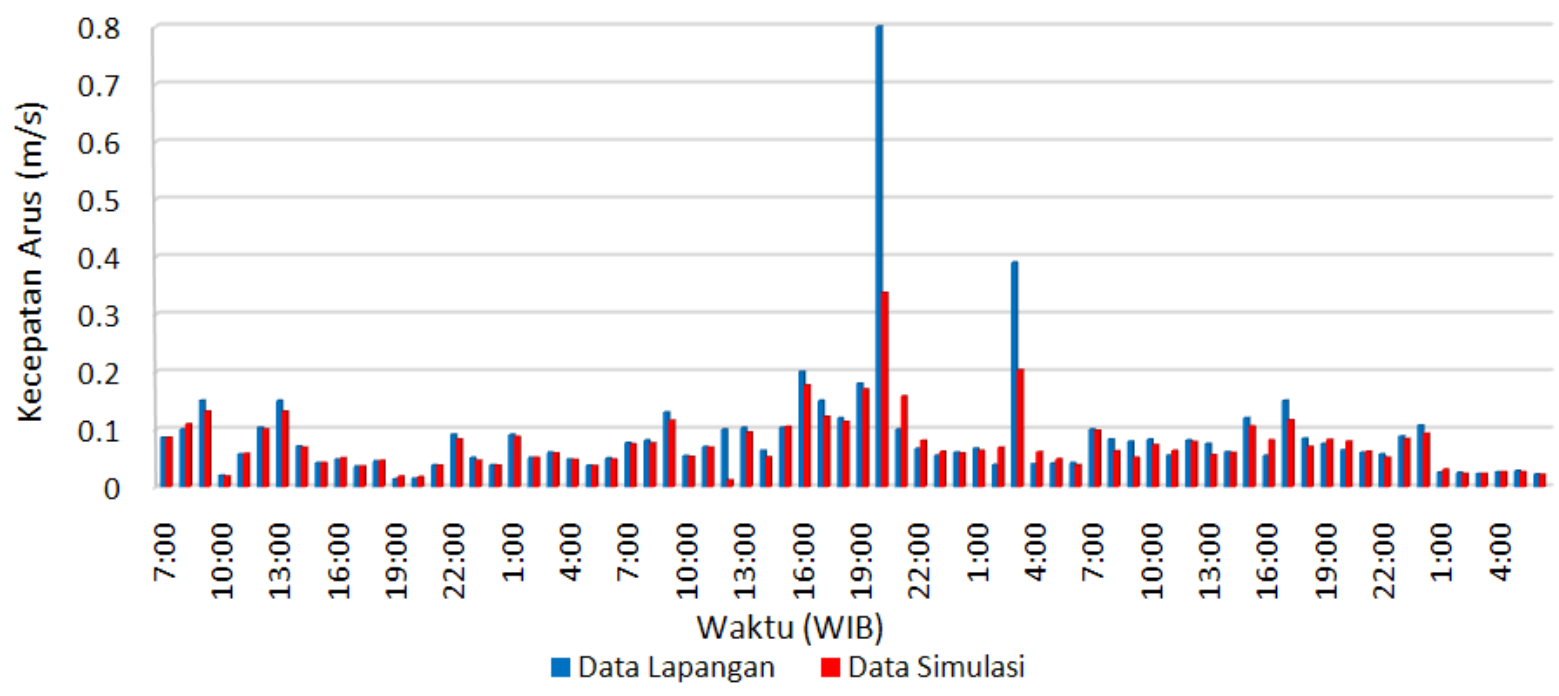

Gambar 3. Grafik Perbandingan Data Kecepatan Arus Hasil SimulasiTerhadap Data Lapangan Tanggal 16 s.d.19 Desember 2008 


\subsection{Musim Barat}

\subsubsection{Elevasi Muka Air Laut}

Elevasi muka air laut pada saat surut menuju pasang tertinggi di perairan pantai Sungai Duri berkisar antara 0,11 s.d. 0,15 m, di muara berkisar antara 0,15 s.d. 0,16 $\mathrm{m}$ dan di sungai berkisar antara 0,16 s.d. 0,17 m. Elevasi muka air laut di perairan pantai pada saat pasang tertinggi berkisar antara 0,39 s.d. 0,42 m, di muara berkisar antara 0,41 s.d. 0,42 $\mathrm{m}$ dan di sungai berkisar antara 0,42 s.d. 0,44 m. Elevasi muka air laut di perairan pantai pada saat pasang menuju surut terendah berkisar antara 0,02 s.d. 0,02 m, di muara berkisar antara 0,02 s.d. 0,03 $\mathrm{m}$ dan di sungai berkisar antara 0,03 s.d. 0,04 m. Sedangkan, elevasi muka air laut di perairan pantai pada saat surut terendah berkisar antara $-0,30$ s.d. $-0,25 \mathrm{~m}$, di muara berkisar antara $-0,25$ s.d. $-0,24 \mathrm{~m}$ sedangkan di sungai berkisar antara $-0,30$ s.d. $-0,24 \mathrm{~m}$.

\subsubsection{Kecepatan dan Arah Arus}

Kecepatan arus di perairan pantai saat surut menuju pasang tertinggi berkisar antara 0,05 s.d. $0,60 \mathrm{~m} / \mathrm{s}$, di muara berkisar antara $0,05 \mathrm{s.d}$. $0,10 \mathrm{~m} / \mathrm{s}$ dan di sungai berkisar antara 0,05 s.d. 0,10 m/s (Gambar 4). Arah arus di perairan pantai bergerak ke arah Barat Laut hingga Utara, di muara sungai arus bergerak ke arah Barat Laut dan di sungai arah arus bervariasi yaitu bergerak ke Barat, Barat Laut hingga Utara. Kecepatan arus pada saat pasang tertinggi di perairan pantai berkisar antara 0,02 s.d. 0,15 $\mathrm{m} / \mathrm{s}$, di muara berkisar antara 0,02 s.d. 0,04 m/s dan di sungai berkisar antara 0,04 s.d. $0,08 \mathrm{~m} / \mathrm{s}$ (Gambar 5). Arah arus di perairan pantai bergerak ke arah Barat Daya, di muara sungai arus bergerak ke arah Barat Daya hingga Barat, sedangkan di sungai arah arus bervariasi yaitu bergerak ke Barat, Barat Laut hingga Utara.

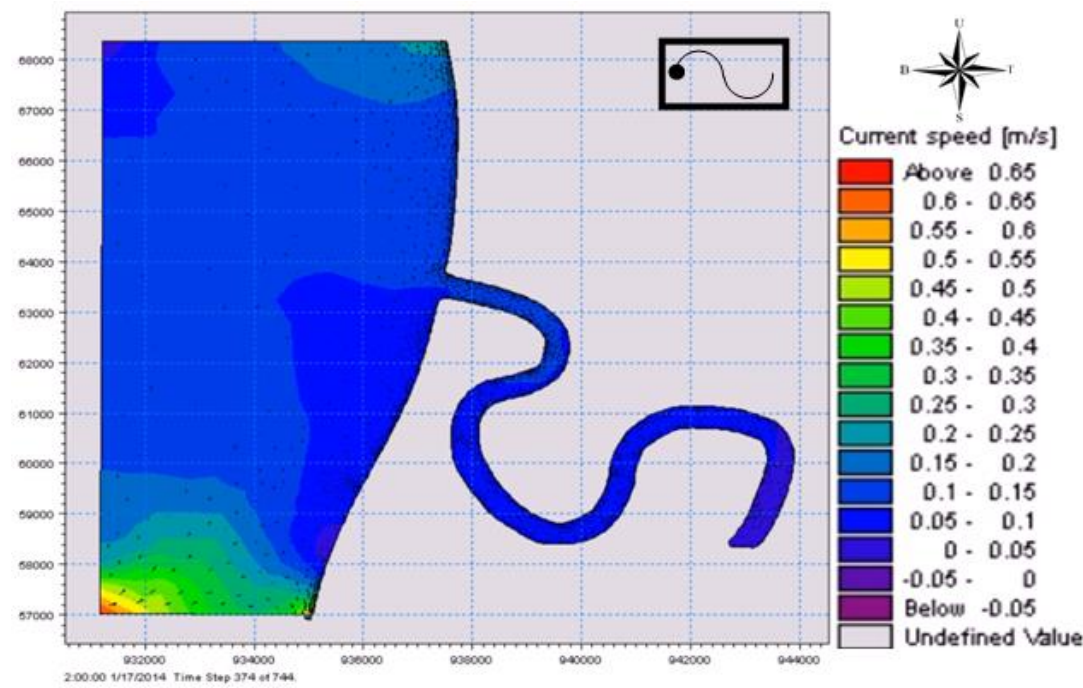

Gambar 4. Kecepatan Arus Hasil Simulasi Model saat Surut Menuju Pasang Tertinggi di Musim Barat

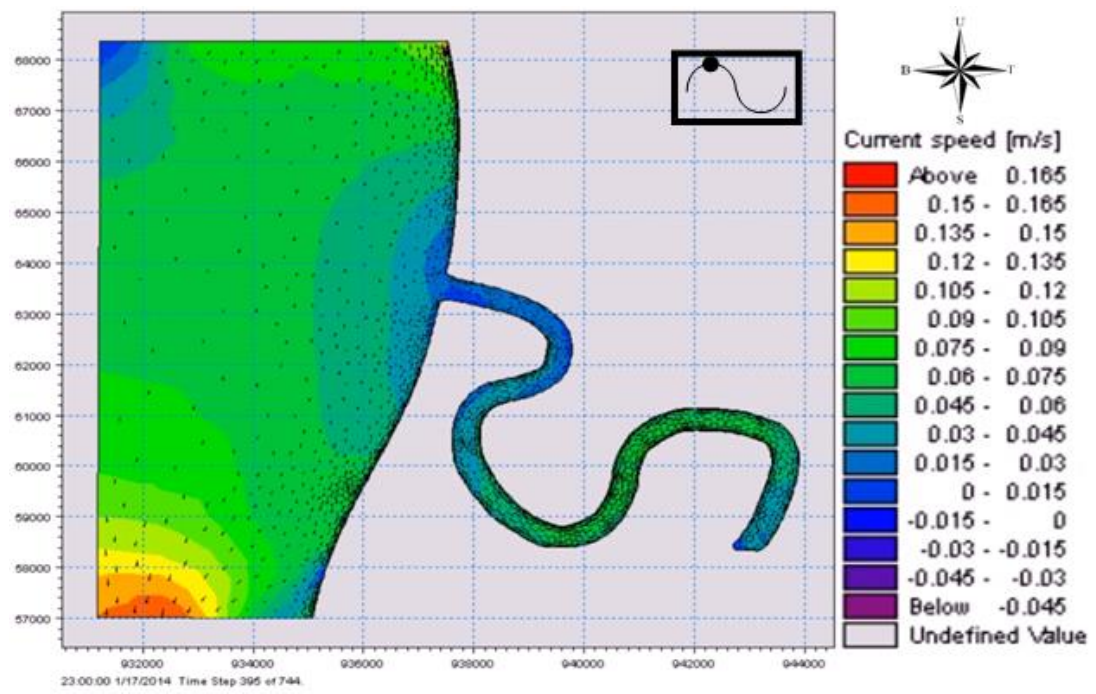

Gambar 5. Kecepatan Arus Hasil Simulasi Model saat Pasang Tertinggi di Musim Barat 


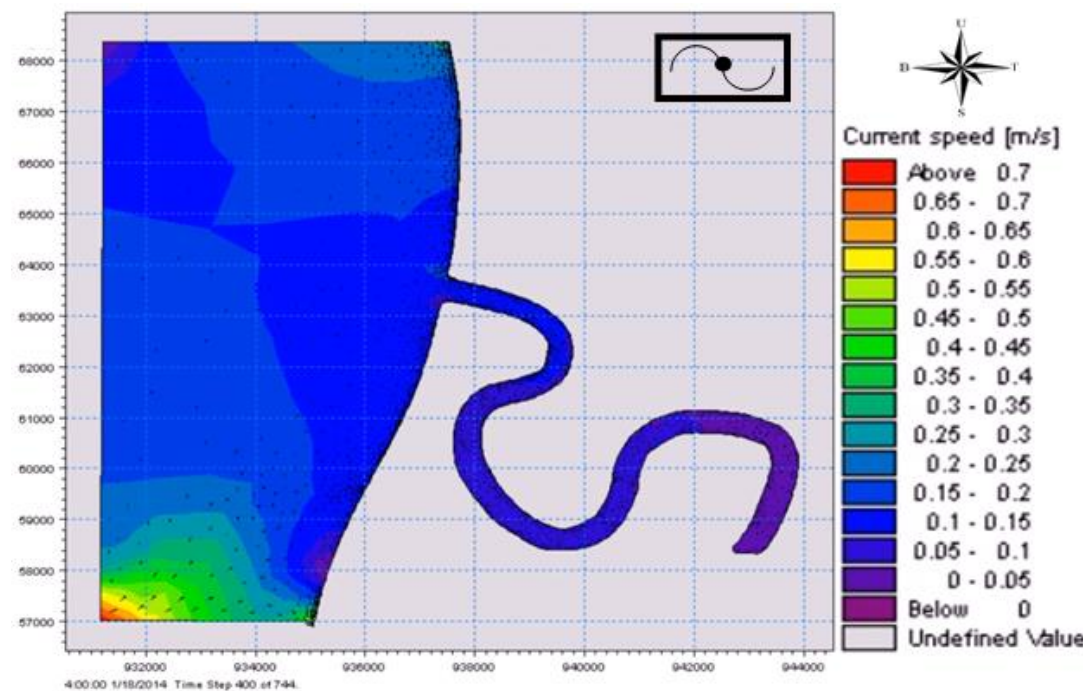

Gambar 6. Kecepatan Arus Hasil Simulasi Model saat Pasang Menuju Surut Terendahdi Musim Barat

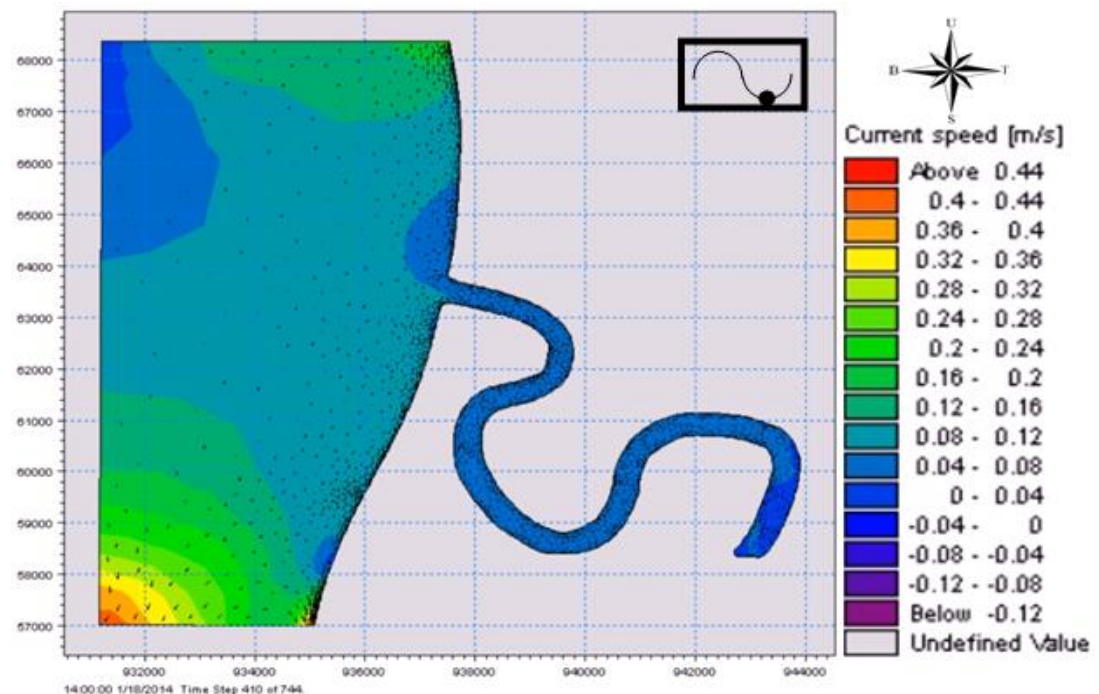

Gambar 7. Kecepatan Arus Hasil Simulasi Model saat Surut Terendah di Musim Barat

Kondisi pasang menuju surut terendah,kecepatan arus di perairan pantai berkisar antara 0,10 s.d. 0,65 m/s, di muara berkisar antara 0,10 s.d. 0,15 m/s dan di sungai berkisar antara 0,05 s.d. 0,10 m/s (Gambar 6). Arah arus di perairan pantai bergerak ke arah Barat Laut hingga Utara, di muara sungai arus bergerak kearah Barat Laut dan di sungai arah arus bervariasi yaitu bergerak ke Barat, Barat Laut hingga Utara. Sedangkan kecepatan arus di perairan pantai pada saat surut terendah berkisar antara 0,04 s.d. $0,40 \mathrm{~m} / \mathrm{s}$, di muara berkisar antara 0,04 s.d. $0,08 \mathrm{~m} / \mathrm{s}$, di sungai berkisar antara 0,08 s.d. 0,12 m/s (Gambar 7). Arah arus di perairan pantai bergerak ke arah Barat Daya, di muara sungai arus bergerak ke arah Barat Daya hingga Barat, sedangkan di sungai arah arus bervariasi yaitu bergerak ke Barat, Barat Laut hingga Utara.

\subsection{Kondisi Peralihan I \\ 3.3.1 Elevasi Muka Air Laut}

Saat keadaan surut menuju pasang tertinggi elevasi muka air laut di perairan pantai Sungai Duri berkisar antara 0,06 s.d. 0,10 m, di muara berkisar antara 0,09 s.d. 0,10 $\mathrm{m}$ dan di sungai berkisar antara 0,10 s.d. 0,12 m. Elevasi muka air laut di perairan pantai pada saat pasang tertinggi berkisar antara 0,23 s.d. $0,25 \mathrm{~m}$, di muara berkisar antara 0,25 s.d. 0,26 m, sedangkan di sungai berkisar antara 0,26 s.d. 0,29 m. Elevasi muka air laut di perairan pantai pada saat pasang menuju surut terendah berkisar antara 0,02 s.d. 0,05 m, di muara berkisar antara 0,04 s.d. 0,06 m sedangkan di sungai berkisar antara 0,05 s.d. 0,08 m. Sedangkan, elevasi muka air laut di perairan pantai pada saat surut terendah berkisar antara $-0,19$ s.d. $-0,17 \mathrm{~m}$, di muara berkisar antara $-0,16$ s.d. $-0,15 \mathrm{~m}$, sedangkan di sungai berkisar antara $-0,17$ s.d. $-0,16$ m. 


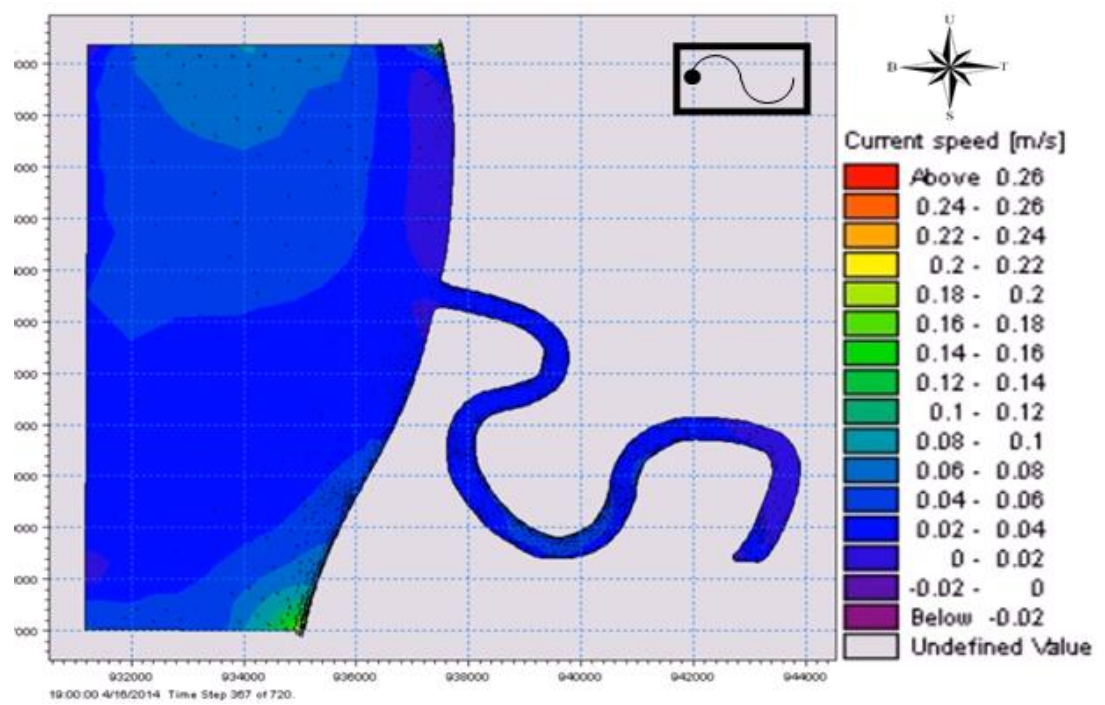

Gambar 8. Kecepatan Arus Hasil Simulasi Model saat Surut Menuju Pasang Tertinggi Kondisi Peralihan 1

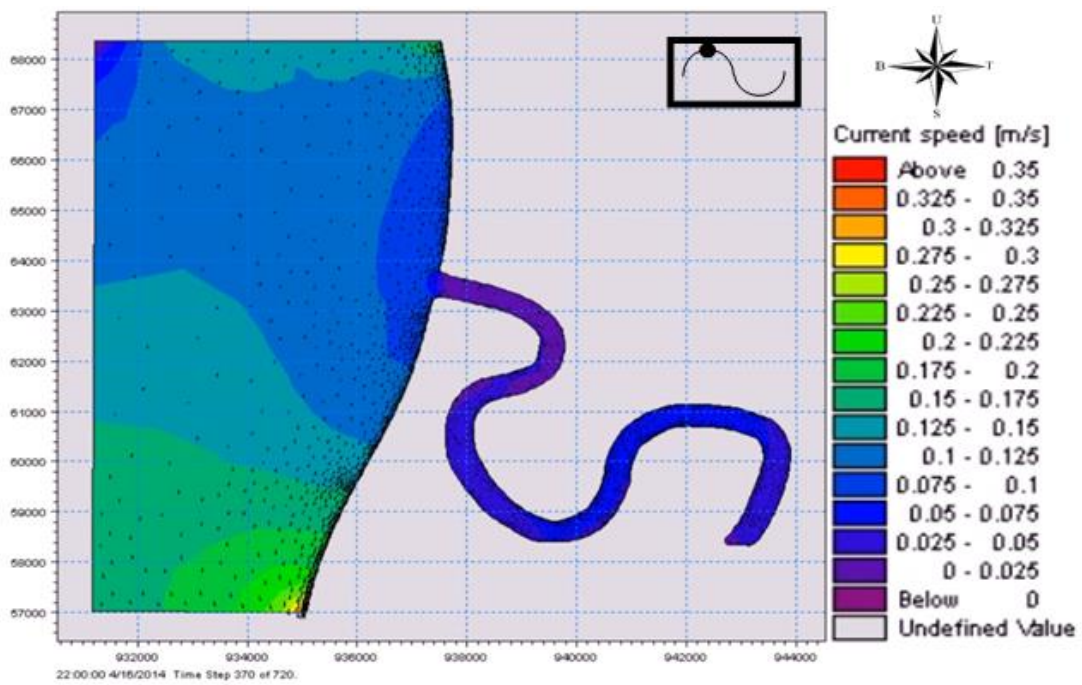

Gambar 9. Kecepatan Arus Hasil Simulasi Model saat Pasang Tertinggi Kondisi Peralihan 1

\subsubsection{Kecepatan dan Arah Arus}

Nilai kecepatan arus diperairan pantai saat surut menuju pasang tertinggiberkisar antara 0,02 s.d. $0,12 \mathrm{~m} / \mathrm{s}$, di muara berkisar antara 0,02 s.d. $0,08 \mathrm{~m} / \mathrm{s}$, di sungai berkisar antara 0,02 s.d. $0,06 \mathrm{~m} / \mathrm{s}$ (Gambar 8). Arah arus di perairan pantai bergerak ke arah Tenggara hingga Barat Daya, di muara sungai arus bergerak ke arah Timur Laut hingga Tenggara dan di sungai arus bergerak ke arah Selatan hingga Barat. Kecepatan arus di perairan pantai pada saat pasang tertinggi berkisar antara 0,03 s.d. 0,30 $\mathrm{m} / \mathrm{s}$, di muara berkisar antara 0,03 s.d. $0,05 \mathrm{~m} / \mathrm{s}$, di sungai berkisar antara 0,03 s.d. 0,05 m/s (Gambar 9). Arah arus di perairan pantai bergerak ke arah Barat Daya, di muara sungai arus bergerak ke arah Barat Daya hingga Barat, sedangkan di sungai arah arus bervariasi yaitu bergerak ke Barat, Barat Laut hingga Utara.
Arah arus di perairan pantai pada saat pasang menuju surut terendah bergerak ke arah Barat Laut hingga Utara, di muara sungai arus bergerak ke arah Barat Laut dan di sungai arah arus bervariasi yaitu bergerak ke Barat, Barat Laut hingga Utara. Kecepatan arus di perairan pantai berkisar antara 0,03 s.d. 0,15 m/s, di muara berkisar antara 0,03 s.d. 0,05 m/s, dan di sungai berkisar antara 0,03 s.d. 0,08 m/s (Gambar 10). Kecepatan arus di perairan pantai pada saat surut terendah berkisar antara 0,02 s.d. $0,14 \mathrm{~m} / \mathrm{s}$, di muara sungai berkisar antara 0,02 s.d. $0,06 \mathrm{~m} / \mathrm{s}$ sedangkan di sungai berkisar antara 0,03 s.d. 0,06 m/s (Gambar 11). Arah arus di perairan pantai bergerak ke arah Barat Daya, di muara sungai arus bergerak ke arah Barat Daya hingga Barat, sedangkan di sungai arah arus bervariasi yaitu bergerak ke Barat, Barat Laut hingga Utara. 


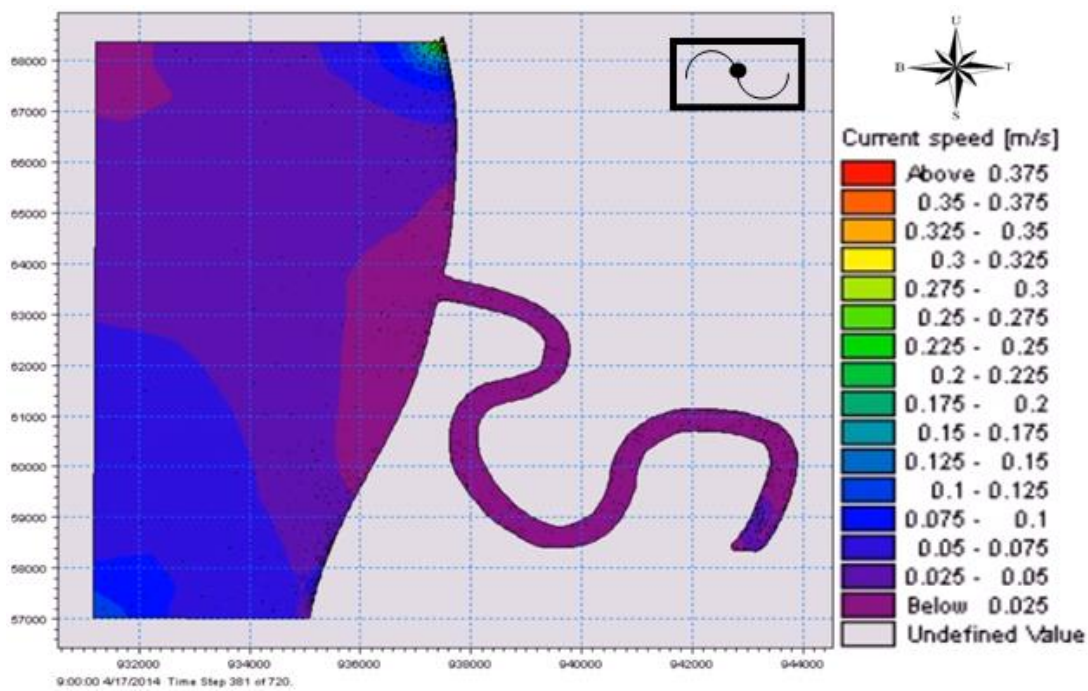

Gambar 10. Kecepatan Arus Hasil Simulasi Model saat Pasang Menuju Surut Terendah Kondisi Peralihan 1

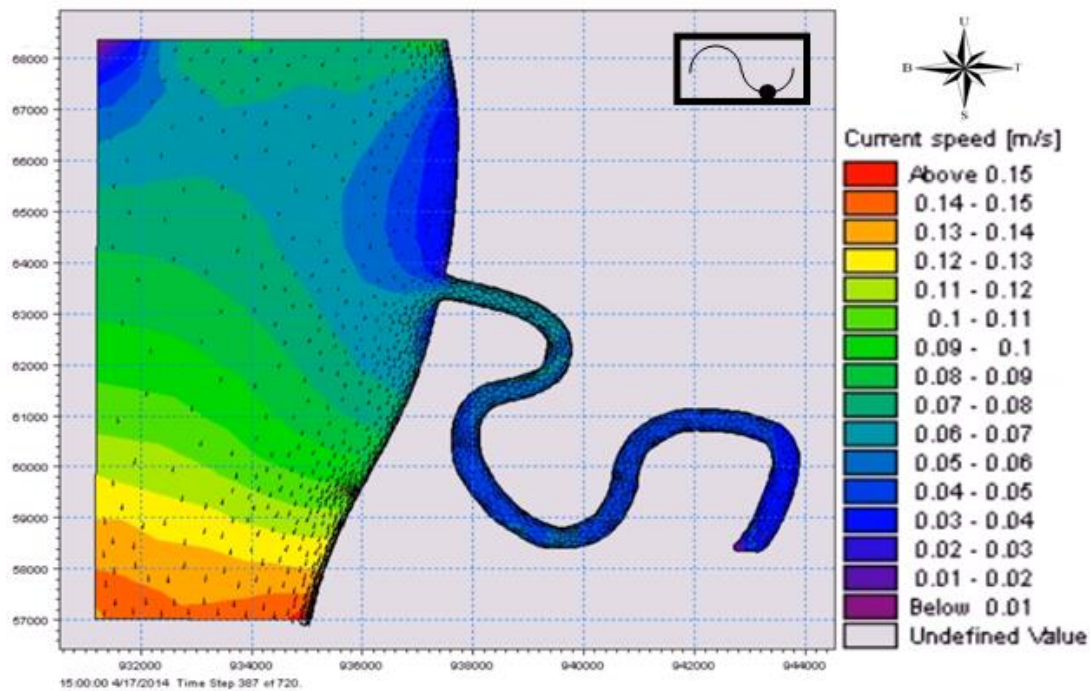

Gambar 11. Kecepatan Arus Hasil Simulasi Model saat Surut Terendah Kondisi Peralihan 1

\subsection{Musim Timur \\ 3.4.1 Elevasi Muka Air Laut}

Kondisi surut menuju pasang tertinggidi perairan pantai Sungai Duri pada musim Timur memiliki nilai elevasi muka air laut berkisar antara 0,09 s.d. $0,14 \mathrm{~m}$, di muara sungai berkisar antara 0,13 s.d. $0,14 \mathrm{~m}$ sedangkan di sungai berkisar antara 0,13 s.d. 0,15 m. Elevasi muka air laut di perairan pantai pada saat pasang tertinggi berkisar antara 0,29 s.d. $0,33 \mathrm{~m}$, di muara berkisar antara 0,32 s.d. 0,33 m, sedangkan di sungai berkisar antara 0,33 s.d. 0,34 m. Elevasi muka air laut di perairan patai pada saat pasang menuju surut terendah berkisar antara 0,01 s.d. 0,06 m, di muara berkisar antara 0,05 s.d. 0,06 $\mathrm{m}$ dan di sungai berkisar antara 0,04 s.d. 0,06 m. Sedangkan, elevasi muka air laut di perairan pantai pada saat surut terendah berkisar antara $-0,23$ s.d. $0,18 \mathrm{~m}$, di muara berkisar antara $-0,18$ s.d. $-0,17$ $m$ sedangkan di sungai berkisar antara $-0,18$ s.d. $-0,17 \mathrm{~m}$.

\subsubsection{Kecepatan dan Arah Arus}

Besar kecepatan arus di perairan pantai saat surut menuju pasang tertinggi berkisar antara 0,04 s.d. $0,24 \mathrm{~m} / \mathrm{s}$, di muara berkisar antara 0,04 s.d. $0,20 \mathrm{~m} / \mathrm{s}$ sedangkan di sungai berkisar antara 0,04 s.d. 0,16 m/s (Gambar 12). Arah arus di perairan pantai bergerak ke arah Barat Laut hingga Utara, di muara sungai arus bergerak ke arah Barat Laut dan di sungai arah arus bervariasi yaitu bergerak ke Barat, Barat Laut hingga Utara. Kecepatan arus di perairan pantai pada saat pasang tertinggi berkisar antara 0,02 s.d. $0,09 \mathrm{~m} / \mathrm{s}$, di muara berkisar antara 0,02 s.d. 0,03 m/s dan di sungai berkisar antara 0,03 s.d. 0,09 m/s (Gambar 13). Arah arus di perairan pantai bergerak ke arah Barat Laut hingga Timur Laut, di muara sungai arus bergerak ke arah Barat Laut dan di sungai arah arus bervariasi yaitu bergerak ke Barat, Barat Laut hingga Utara. 


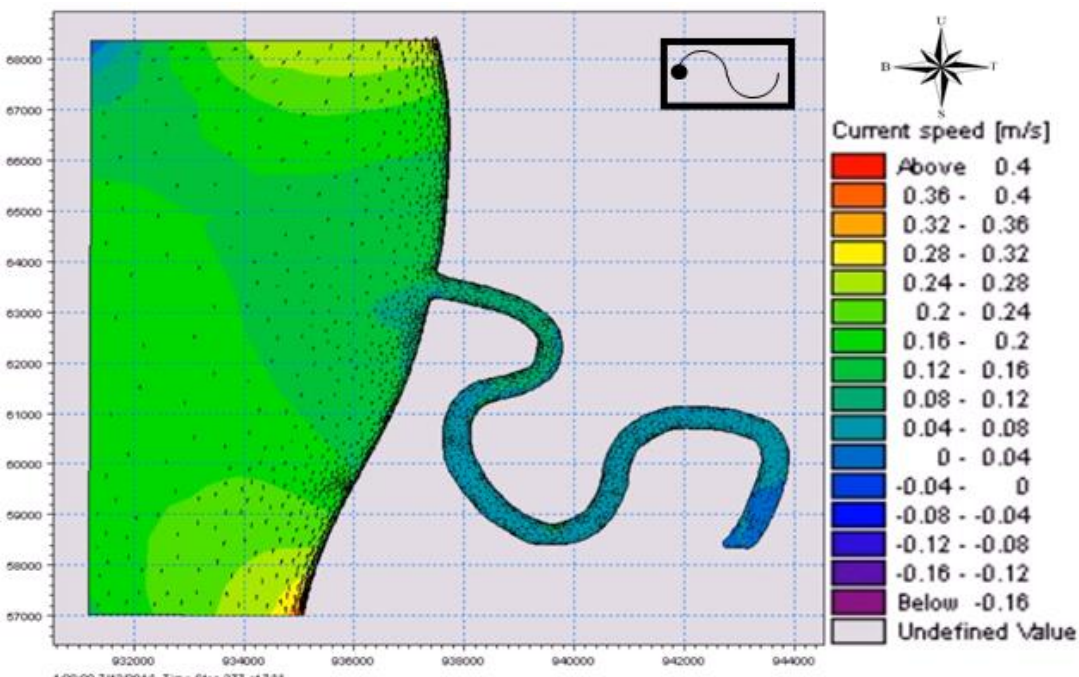

Gambar 12. Kecepatan Arus Hasil Simulasi Model saat Surut Menuju Pasang Tertinggidi Musim Timur

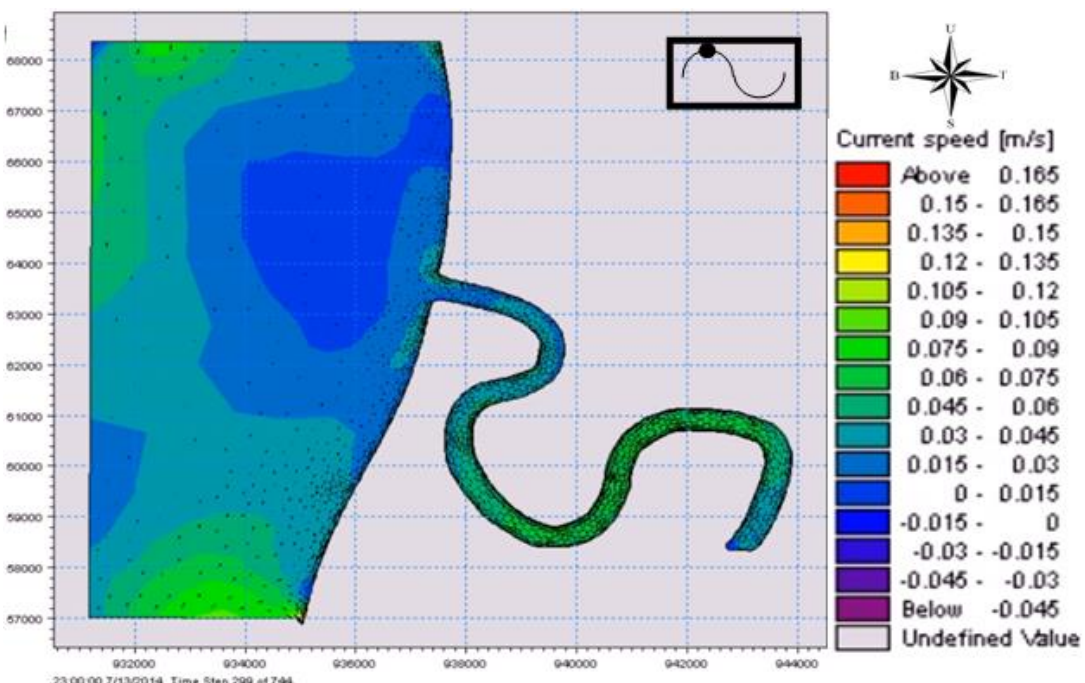

Gambar 13. Kecepatan Arus Hasil Simulasi Model saat Pasang Tertinggi di Musim Timur

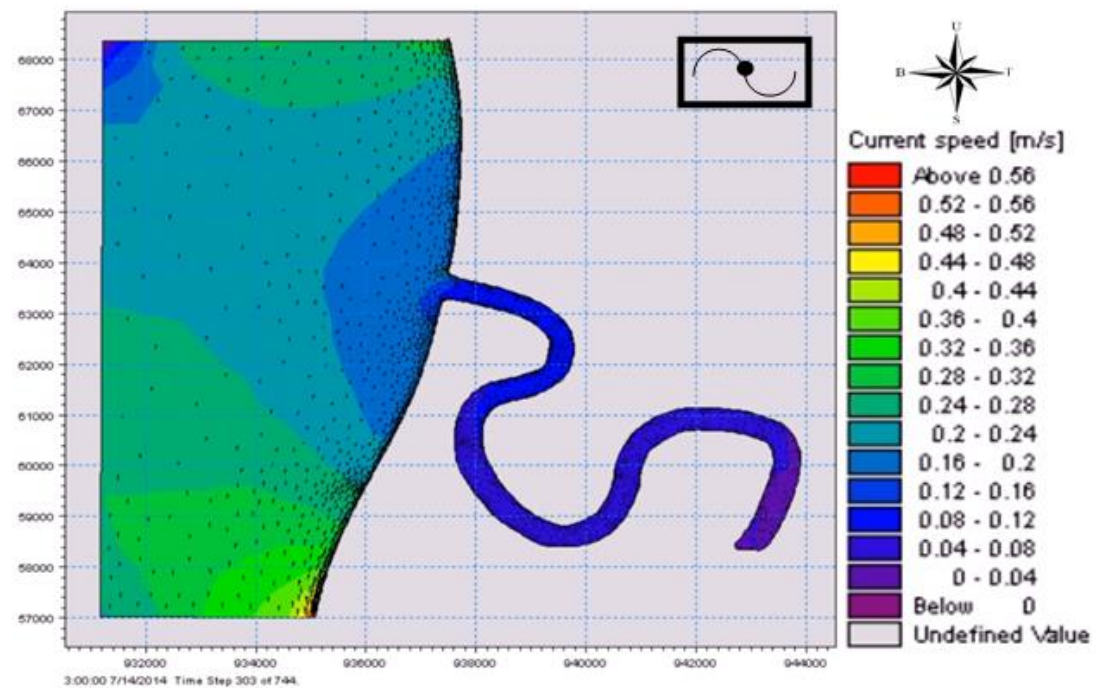

Gambar 14. Kecepatan Arus Hasil Simulasi Model saat Pasang Menuju Surut Terendah di Musim Timur 


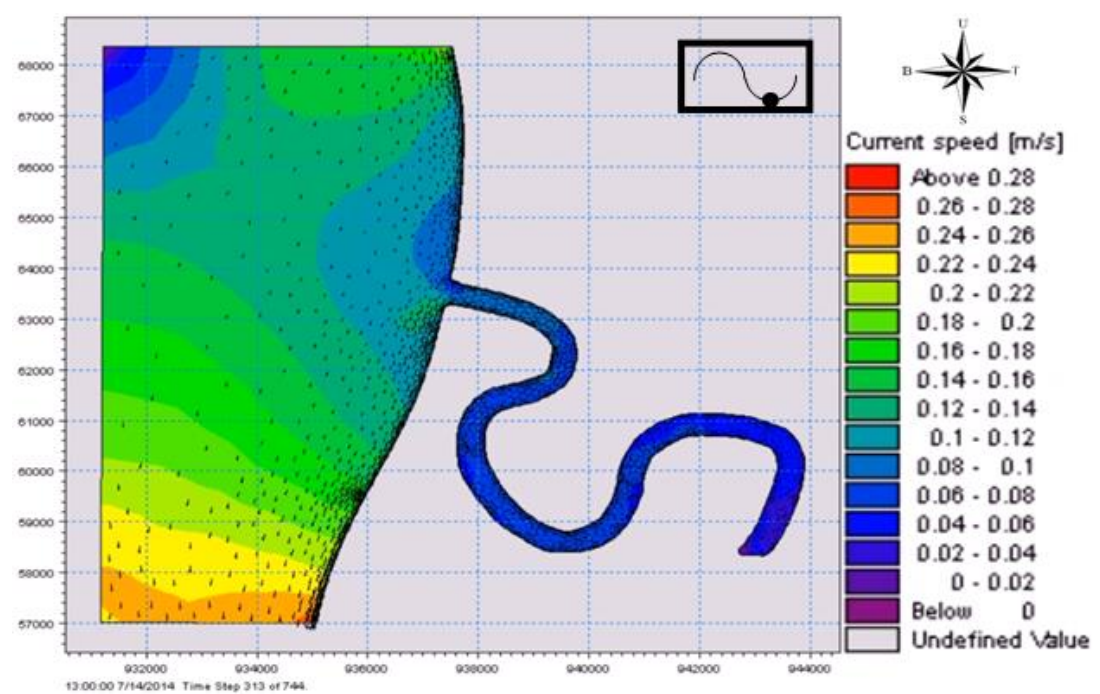

Gambar 15. Kecepatan Arus Hasil Simulasi Model saat Surut Terendah di Musim Timur

Nilai kecepatan arus di perairan pantai pada saat pasang menuju surut terendah berkisar antara 0,08 s.d. $0,44 \mathrm{~m} / \mathrm{s}$, di muara berkisar antara 0,08 s.d. $0,16 \mathrm{~m} / \mathrm{s}$ sedangkan di sungai berkisar antara 0,04 s.d. 0,16 m/s (Gambar 14). Arah arus di perairan pantai bergerak ke arah Barat Laut hingga Utara, di muara sungai arus bergerak ke arah Barat Laut dan di sungai arah arus bervariasi yaitu bergerak ke Barat, Barat Laut hingga Utara. Kecepatan arus di perairan pantai pada saat surut terendah berkisar antara 0,02 s.d. $0,24 \mathrm{~m} / \mathrm{s}$, di muara berkisar antara 0,02 s.d. $0,14 \mathrm{~m} / \mathrm{s}$ sedangkan di sungai berkisar antara 0,02 s.d. 0,08 m/s (Gambar 15). Arah arus di perairan pantai bergerak ke arah Barat Daya, di muara sungai arus bergerak ke arah Barat Daya hingga Barat, sedangkan di sungai arah arus bervariasi yaitu bergerak ke Barat, Barat Laut hingga Utara.

\subsection{Kondisi Peralihan II}

\subsubsection{Elevasi Muka Air Laut}

Pada kondisi peralihan II, elevasi muka air laut pada saat surut menuju pasang tertinggi di perairan pantai Sungai Duri berkisar antara 0,04 s.d. $0,01 \mathrm{~m}$, di muara berkisar $0,01 \mathrm{~m}$ sedangkan di sungai berkisar 0,01 m. Elevasi muka air laut di perairan pantai pada saat pasang tertinggi berkisar antara $-0,05$ s.d. 0,08 $\mathrm{m}$, di muara berkisar antara 0,06 s.d. 0,08 m, sedangkan di sungai berkisar antara 0,07 s.d. 0,09 m. Elevasi muka air laut di perairan pantai pada saat pasang menuju surut terendah berkisar antara $-0,04$ s.d. 0,01 m, di muara sungai berkisar antara $-0,01$ s.d. $0,01 \mathrm{~m}$ sedangkan di sungai berkisar 0,01 $\mathrm{m}$. Sedangkan, elevasi muka air laut di perairan pantai pada saat surut terendah berkisar antara $-0,10$ s.d. $-0,06 \mathrm{~m}$, di muara sungai berkisar antara $-0,07$ s.d. $-0,06 \mathrm{~m}$ dan di sungai berkisar antara $-0,06$ s.d. $-0,05 \mathrm{~m}$.

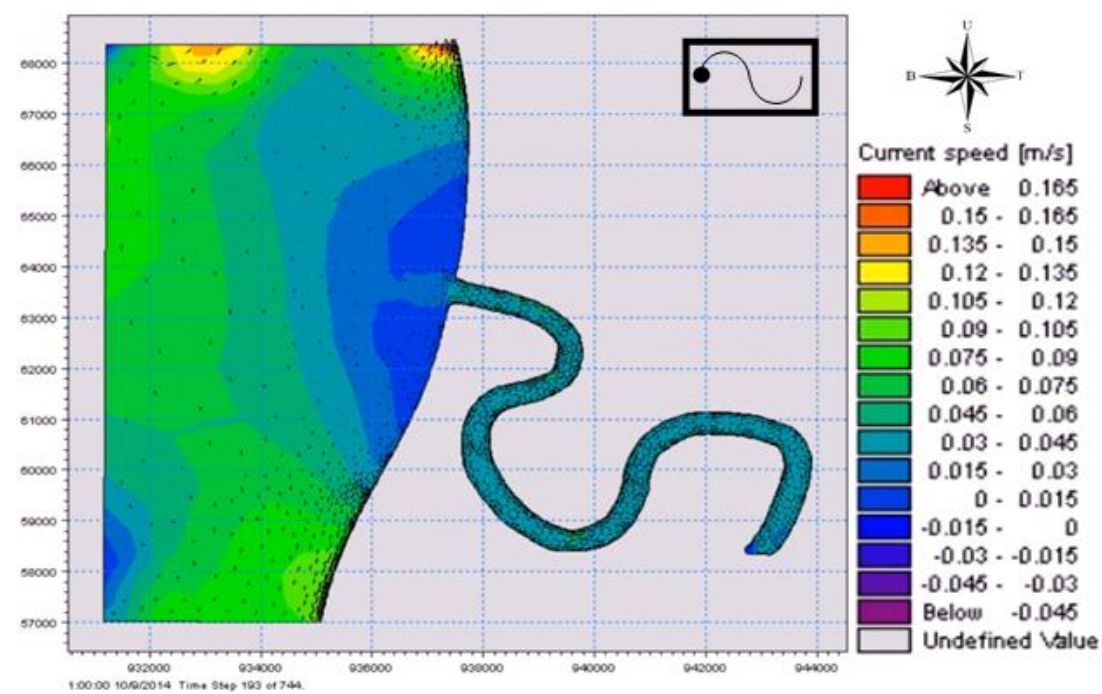

Gambar 16. Kecepatan Arus Hasil Simulasi Model saat Surut Menuju Pasang Tertinggi Kondisi Peralihan II 


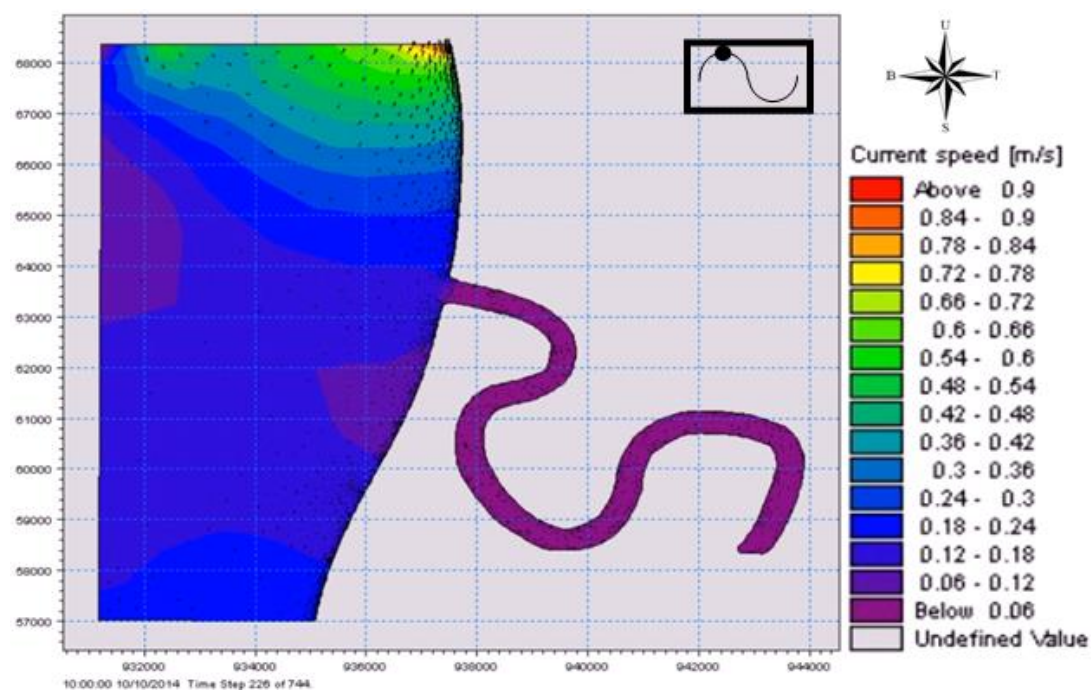

Gambar 17. Kecepatan Arus Hasil Simulasi Model saat Pasang Tertinggi Kondisi Peralihan II

\subsubsection{Kecepatan dan Arah Arus}

Hasil simulasi menunjukkan kecepatan arus di perairan pantai saat surut menuju pasang tertinggi berkisar antara 0,02 s.d. 0,14 m/s, di muara berkisar antara 0,03 s.d. $0,05 \mathrm{~m} / \mathrm{s}$ sedangkan di sungai berkisar antara 0,02 s.d. $0,05 \mathrm{~m} / \mathrm{s}$ (Gambar 16). Arah arus di perairan pantai bergerak ke arah Barat Laut hingga Timur Laut, di muara sungai arus bergerak ke arah Barat Laut dan di sungai arah arus bervariasi yaitu bergerak ke Barat, Barat Laut hingga Utara. Kecepatan arus di perairan pantai pada saat pasang tertinggi berkisar antara 0,06 s.d. $0,72 \mathrm{~m} / \mathrm{s}$, di muara sungai berkisar antara 0,06 s.d. $0,18 \mathrm{~m} / \mathrm{s}$ sedangkan di sungai berkisar antara 0,06 s.d. 0,12 m/s (Gambar 17). Arah arus di perairan pantai bergerak ke arah Barat Laut hingga Utara, di muara sungai arus bergerak ke arah Barat Laut dan di sungai arah arus bervariasi yaitu bergerak ke Barat, Barat Laut hingga Utara.
Kecepatan arus di perairan pantai pada saat pasang menuju surut terendah berkisar antara 0,02 s.d. $0,16 \mathrm{~m} / \mathrm{s}$, di muara sungai berkisar antara 0,02 s.d. 0,06 m/s sedangkan di sungai berkisar antara 0,02 s.d. 0,04 m/s (Gambar 18). Arah arus di perairan pantai bergerak ke arah Barat Daya hingga Barat, di muara sungai arus bergerak ke arah Barat Daya hingga Barat dan di sungai arah arus bervariasi yaitu bergerak ke Barat, Barat Laut hingga Utara. Kecepatan arus di perairan pantai pada saat surut terendah berkisar antara 0,10 s.d. 0,50 m/s, di muara sungai berkisar antara 0,05 s.d. $0,10 \mathrm{~m} / \mathrm{s}$ sedangkan di sungai berkisar antara 0,05 s.d. $0,10 \mathrm{~m} / \mathrm{s}$ (Gambar 19). Arah arus di perairan pantai bergerak ke arah Barat Daya hingga Barat, di muara sungai arus bergerak ke arah Barat Daya hingga Barat dan di sungai arah arus bervariasi yaitu bergerak ke Barat, Barat Laut hingga Utara.

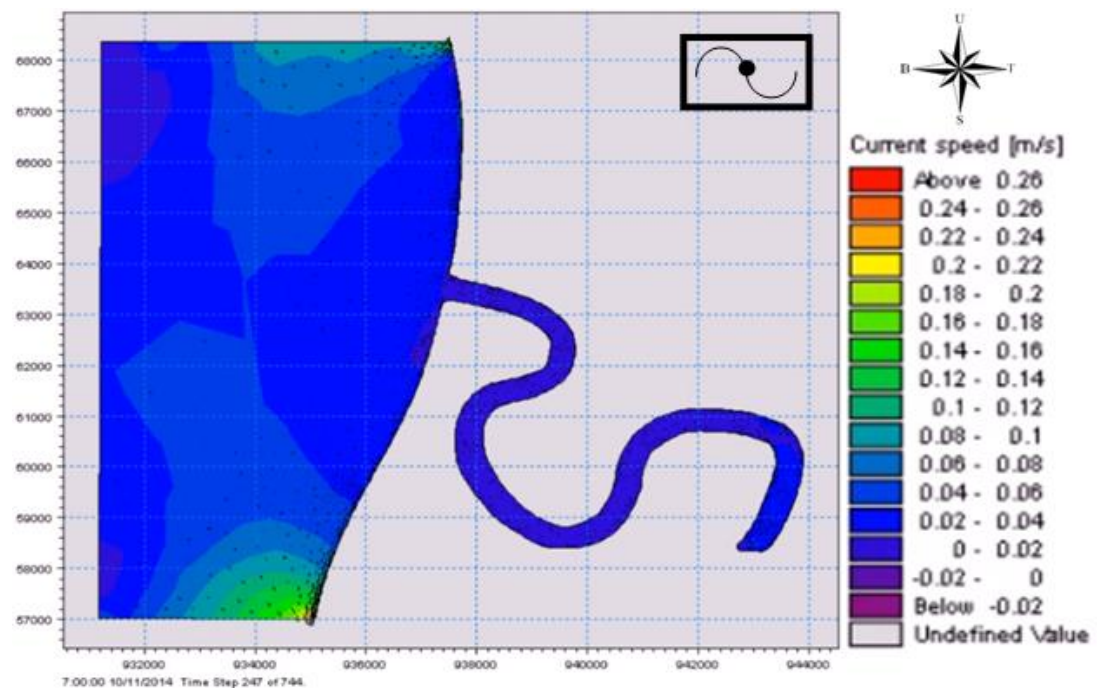

Gambar 18. Kecepatan Arus Hasil Simulasi Model saat Pasang Menuju Surut Terendah Kondisi Peralihan II 


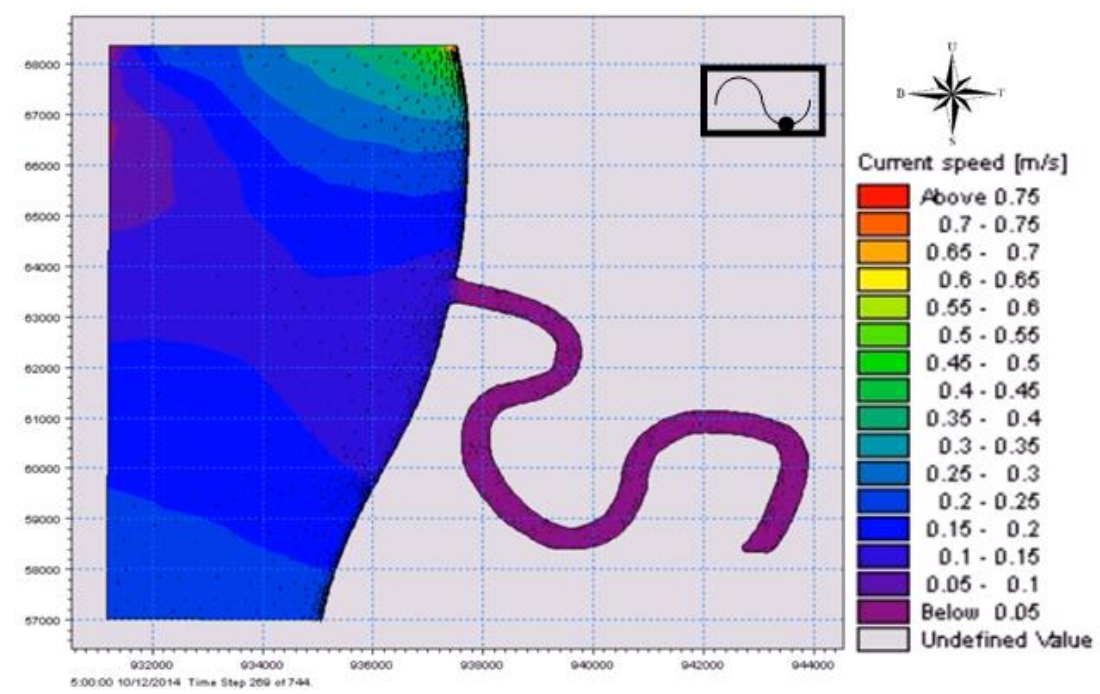

Gambar 19. Kecepatan Arus Hasil Simulasi Model saat Surut Terendah Kondisi Peralihan II

\section{Kesimpulan}

Secara umum elevasi muka air laut pada kondisi musim Barat berkisar antara -0,30 s.d. 0,44 m, kecepatan arus di musim Barat berkisar antara 0,02 s.d. 0,65 m/s, dengan arah Utara hingga Barat Daya. Sedangkan elevasi muka air laut pada kondisi Peralihan I berkisar antara 0,19 s.d. $0,29 \mathrm{~m}$, kecepatan arus berkisar antara 0,02 s.d. 0,30 m/s, dengan arah Timur Laut hingga Tenggara. Elevasi muka air laut pada kondisi musim Timur berkisar antara $-0,23$ s.d. 0,34 m, kecepatan arus di musim Timur berkisar antara 0,02 s.d. 0,44 m/s, dengan arah Utara hingga Barat Daya. Sedangkan elevasi muka air laut pada kondisi Peralihan II berkisar antara 0,10 s.d. 0,09 m, kecepatan arus berkisar antara 0,02 s.d. $0,72 \mathrm{~m} / \mathrm{s}$, dengan arah Barat hingga Tenggara.

\section{DAFTAR PUSTAKA}

[1] Badan Pusat Statistik Kota Pontianak. Pontianak dalam Angka 2010. Pontianak: BPS Kota Pontianak; 2010.

[2] Agustini T, Jumarang MI, Ihwan A. Simulasi Pola Sirkulasi Arus di Muara Kapuas Kalimantan Barat. PRISMA FISIKA. 2013; I: p. 33-39.

[3] Google Earth. Sungai Duri Kalimantan Barat. $0,571228^{\circ} \mathrm{LU}, 108,928178^{\circ} \mathrm{BT}$, Ketinggian Mata 3081 meter.CNES/Atrium; 2015 [09 Juli 2015] http://www.earth.google.com/

[4] ECMWF. European Center for Medium Range Weather Forecast; 2014 [01 Juli2015] http://www.apps.ecmwf.int/

[5] DHI Water and Environment. Hydrodynamic and Transport Module Scientific Documentation. Denmark; 2007.
[6] Padman L, Erofeeva S. Tide Model Driver (TMD) Manual V 1.2: Earth \& Space Research; 2005.

[7] Chai T, Draxler RR. Root Mean Square Error (RMSE) or Man Absolute Error (MAE). Geoscientific Model Development. 2014; VII: p. 1247-1250.

[8] Sulvina. Analisis Kecepatan Arus dan Pola Angkutan Sedimen pada Pantai di Daerah Sungai Duri Kecamatan Sungai Kunyit Kabupaten Pontianak. Pontianak: Fakultas Matematika dan Ilmu Pengetahuan Alam Universitas Tanjungpura; 2009. 